upon a surface of calm water, they are, in part, reflected according to the usual law, and $a$ rainbow is then seen by reflection. But the absolute position of the bow changes with every change in the position of the observer's eye; hence the bow seen mirrored in the pool is not the reflection of that seen at the same time directly in the heavens. Suppose the shower to be fixed in space, then the drops which produce the bow seen directly, would not be those which produce the bow as seen by reflection.

In the paragraph to which your correspondent "Z.X.Y." has called attention, I meant to combat the notion, entertained by many, that the rainbow is reflected after the fashion of an ordinary floating cloud which emits light in all directions, and which, by the light thus emitted, paints its image in the water. A few additional words might have made my meaning clearer; but as I was dealing at the time more with historic statement than with scientific exposition, I desired to be brief. I can hardly think, however, that your correspondent will be angry with me for giving him what must have been agreeable as well as successful occupation at the Falls of the Rhine.

Royal Institution, Sept. 15 JOHN TYNDALL

\section{Original Research at the Universities}

MY attention has been arrested by the following sentence in the extract given by you from Prof. Frankland's cvidence before the Science Commission :- "I believe that one cause (of the slow progress of original research in England) lies in the entire non-recognition of original research by any of our Universities. Even the University of London, which has been foremost in advancing instruction in experimental science, gives its highest degree in Science without requiring any proof that the candidate possesses the faculty of original research, or is competent to extend the boundaries of the science in which he graduates."

It may interest Dr. Frankland and those who take the same view as he does, to know that this subject has engaged the attention of the graduates of the University of London. At a meeting of the Annual Committee of Convocation in December last, it was moved by Prof. Guthrie-

"That every candidate for the degrce of Doctor of Science shall be required to submit to his respective Examiners a written dissertation embodying some original research in one or more of the subjects of his intended examination; and that such dissertation be approved before the candidate be allowed to proceed to examination."

This motion $I$ had the honour of seconding ; but the degree of acceptance which the principle involved in it met with from the Committee is seen by the sequel, as stated in the printed minutes, that it was " rejected by a large majority." The exact number, if my memory serves me rightly, were Ayes, 3; Noss, 16; among the Noes ware two Doctors and one Bachelor of Science, and at least five Doctors of Medicine. The "Annual Committce," it may ba stated, is a representative body elected annually by the graduates in Convocation, but has no legislative or auministrative power, this resting entirely with the Senate.

AlfRed IV. BENietT

\section{Endowment of Research}

Wiru regard to the Endowment of Scientific Research, could not this be well placed in the hands (as it now is, to a very limited extent) of a Committee of the Britich Association? the committee being authorised to supply funds for experimental purposes, and the members, say three or four in number, to have a permanent salary for the time spent in the examination of claims from applicants.

It might possibly be desirable that one or more of the com. mitt $s$ should retire every two or threc years and not be eligible for re-election until after the lapse of three years; and also, to prevent waste of time, that all applications for help should be presented only through one or more gentlemen of known scientific attainments, and not of necessity at the instigation of the person to whom the assistance was to be rendered. I believe that this would be a good practical arrangement as regards the poorer class, who are compelled to throw up valuable original researches to supply themselves and those depending on them with homes and food.

The abuse of a trust of this kind would hardly be possible, 28 the help would of necessity be given in those cases where a cer. tain amount of work had already been done under difficulties, and where the natural instinct for original research was of neces. sity strongly developed. The presentation of an annual sum for, say five years, renewable at the end of the time if recessary, would be a godsend to many a man who has allowed himself to starve for the benefit of posterity.

Thos. Fletcher

\section{FERTILISATION OF FLOWERS BY INSECTS *} III.

On the co-existence of two forms of flowits in the same spccies or genus, - a more conspicuous one adapted to cross-firtilisation by insects, and a less conspicuons one adapted to self-fertilisation.

SINCE Darwin, in his admirable work on Orchids, thad proved that the flowers of this family are endowed with an immense variety of comtrivances for cross-fertilisation by insects, it was almost generally admitted by botanists that cross-fertilisation is the rule throughout the whole vegetable kingdom. Darwin's well-known aphorism, that "Nature abhors perpetual self-fertilisation"was exaggerated by his successors in this field of research, Hildebrand in Germany and Delpino in Italy, who, in their various elaborate memoirs on the fertilisation of flowers, repeatedly cxpressed their strong belief that nature abhors self-fertilisation at all. In direct opposition to this opinion, Axell $\ddagger$ propounded the doctrine that the development of the fertilising arrangements in phanerogams has been always an advance, and still continues to advance, in one and the same direction, towards a perfection which affords more and more facilities for self-fertilisation.

My own observations on the contrivances of our flowers and on the insects really visiting and fertilising them, have convinced me, that neither Hildebrand's and Delpino's, nor Axell's opinion is a thoroughly adequate one, but that under certain conditions the facility for selffertilisation is most advantageous to a plant, while, under other conditions, the inevitableness of cross-fertilisation by the visits of insects is the more advantageous.

To all plants the flowers of which possess such a degree of attractiveness for insects that cross-fertilisation by these transporters of pollen is never wanting, the possibility of self-fertilisation is quite useless, and from this cause, not being subjected to the effects of natural selection, may be lost, like any useless peculiarity, and in many instances, indeed, has been lost. On the contrary, to those plants the flowers of which possess so slight a degree of attractiveness for insects, that the transportation of the pollen to the stigma by insects is effected in but very few cases, the possibility of self-fertilisation is most advantageous, and indeed we find in most cases such plants well adapted for self-fertilisation.

Among many facts which I could appeal to as proofs of my statements, there are, I believe, none more instructive than those alluded to in the superscription of this article.

In some species of our wild plants I have found on different plants two different forms of flowers, evidently showing the connectionabove stated between attractiveness for insects and adaptation for inter-crossing or for selffertilisation. As nobody before, for aught I know, has observed this phenomenon, I will give some details of the most important instances hitherto observed.

\section{Lysimachia vulgaris}

of this species specimens with more conspicuous flowers are found in sunny localities. The petals of this form are dark yellow with red at the base, on an average about $12 \mathrm{~mm}$. long, and $6 \mathrm{~mm}$. wide, opening widely and

- Continued from p. 206.

+ "On the Various Contrivances by which British and Foreign Orchids axe Fertilised by Insects." (London, 1863.)

1 In his work: "Om anordningarna för fanerogama växternas befruktning." (Stockholm, 1869.) 